\title{
Joint Ventures
}

\author{
Martin Hoogendoorn
}

Een veel voorkomende wijze van samenwerking tussen ondernemingen is het uitvoeren van activiteiten in de vorm van een joint venture. Een joint venture is bijna altijd een afzonderlijke juridische entiteit. De partners in de joint venture voeren gezamenlijk de zeggenschap uit. In internationaal verband is een joint venture met een lokale partner soms de enige mogelijkheid om in het land voet aan de grond te krijgen. Een joint venture is geen nieuw verschijnsel, maar niettemin was er voldoende reden voor de redactie van het $M A B$ om hieraan een themanummer te wijden. Juist omdat joint ventures inmiddels zo belangrijk zijn geworden, is het zinvol om actuele bedrijfseconomische en accountancy-aspecten met betrekking joint ventures in kaart te brengen. Dat gebeurt in vier artikelen, vanuit vier verschillende invalshoeken: strategie en economie, management control, externe verslaggeving, en accountantscontrole.

De Jong en Kleijn bespreken in het eerste artikel de strategische en economische grondslagen van internationale joint ventures. Daarbij stellen zij zich de volgende centrale vragen:

- Hoe kunnen we de prestaties van internationale joint ventures meten en welke factoren zijn daarvoor bepalend?

- Zijn internationale joint ventures voor Nederland belangrijk?

De eerste vraag wordt beantwoord vanuit de alliantieliteratuur en laat zien dat de prestatiemeting verschillende dimensies kent en dat elke dimensie haar eigen maatstaven heeft. Bij de beantwoording van de tweede vraag wordt gebruik gemaakt van een uniek zelfontwikkeld databestand, waarin gegevens zijn opgenomen van internationale joint ventures van Nederlandse ondernemingen in de periode 1985 tot 2006. Na een hausse in de periode 19901996 blijkt de internationale joint venture als organisatievorm volwassen te zijn geworden en te stabiliseren op een gemiddelde van twintig nieuwe initiatieven per jaar. In de periode tussen 1985 en 2006 werden 752 internationale joint ventures opgericht, de meeste door middelgrote en kleine bedrijven, en veelal in Europa of Azië (vooral China). Het artikel biedt nog diverse andere interessante data, onder andere over de beëindigingen van de joint ventures en de oorzaken daarvan. Belangwekkend daarbij is de bevinding dat slechts één op de vijf Nederlandse joint ventures in de waarnemingsperiode tot een einde is gekomen, hetgeen aanzienlijk minder is dan eerdere schattingen dat 30 tot 50 procent van de allianties in de eerste vijf jaar van het bestaan.

Van der Meer-Kooistra en Kamminga gaan in het tweede artikel in op de rol van management control in joint venture-relaties. Op welke wijze kunnen de partners in de joint venture (door de auteurs 'de moederbedrijven' genoemd) ervoor zorgen dat de samenwerking succesvol is? De auteurs bespreken daarbij drie vraagstukken van management control: het coördinatievraagstuk, het vraagstuk van opportunistisch gedrag en het vraagstuk van het opbouwen van vertrouwen. Zij concluderen dat joint ventures complexe relaties zijn om aan te sturen, omdat de partners niet alleen een relatie hebben met de joint venture, maar ook onderling. De samenwerkingscontracten tussen de partners zijn altijd onvolledig, omdat zich gedurende de samenwerking onvoorziene ontwikkelingen kunnen voordoen waarop de partners moeten reageren. Er kan dan een spanning ontstaan tussen het voortzetten van de samenwerking en het eigenbelang van de individuele partner. Het is daarom in het belang van de voortzetting van de joint venture dat management control niet alleen voorzienbaar opportunistisch gedrag tegengaat, maar ook het opbouwen van een vertrouwensrelatie ondersteunt door coöperatief gedrag te stimuleren. De auteurs geven aan dat het joint venture-contract hierbij zeer belangrijk is en dat bij de start van de samenwerking daaraan veel aandacht moet worden besteed. Het is interessant hier een relatie te leggen met het relatief gering aantal beëindigingen van de Nederlandse internationale joint ventures zoals gerapporteerd door De Jong en Kleijn. Dit lijkt een indicatie dat management control in het algemeen goed geregeld is. Zeker als we daarbij betrekken dat in slechts 3 procent van de door De Jong en Kleijn waarge- 
nomen gevallen de beëindiging veroorzaakt is door belangenconflicten tussen de partners.

Het derde artikel van Eeftink en De Feijter behandelt de verantwoording over joint ventures in de jaarrekening. Vanuit dit gezichtspunt komt het themanummer net iets te vroeg. Bij de planning waren wij ervan uitgegaan dat de International Accounting Standards Board (IASB) inmiddels zijn nieuwe standaard over joint ventures in de jaarrekening het licht zou hebben laten zien, maar de afronding van dit project werd diverse malen uitgesteld. Toch kan uit eerdere voorstellen en reacties daarop al wel worden opgemaakt in welke richting de IASB gaat en de auteurs bespreken dit uitgebreid in hun artikel. Het ziet ernaar uit dat de IASB proportionele consolidatie gaat verbieden, en dat waardering volgens de equity-methode zal moeten plaatsvinden. Er is dan geen verschil meer met de verwerking van belangen in deelnemingen waarop invloed van betekenis in het zakelijk en financieel beleid bestaat. De auteurs geven aan dat vele ondernemingen tot nu toe proportioneel consolideren en dat de wijziging belangrijke gevolgen zal hebben voor de presentatie van de cijfers. Ook geven ze op overtuigende wijze aan dat het argument waarop de keuze van de IASB is gebaseerd nogal beperkt is: de IASB meent dat proportionele consolidatie niet aansluit op de definitie van activa en passiva in het Framework, maar andere elementen van het Framework, zoals de doelstelling van de jaarrekening en het kwalitatieve kenmerk relevantie, hebben zij onvoldoende in hun beschouwing betrokken. Uit empirisch onderzoek blijkt proportionele consolidatie een grotere 'decision usefulness' te kennen dan toepassing van de equity-methode. Wat mij betreft zijn bouwondernemingen die veel in aannemingscombinaties werken een mooi voorbeeld: bij proportionele consolidatie geeft de omzet een goed beeld van het activiteitenniveau van de onderneming, bij toepassing van de equity-methode is dat niet meer het geval. Ik deel daarom de kritiek van de auteurs dat de IASB een bredere en meer fundamentele benadering had moeten kiezen (waarbij ook andere alternatieven dan de equity-methode of proportionele consolidatie in overweging hadden moeten worden genomen). Daarbij kan uit de bevinding dat proportionele consolidatie in strijd is met de definitie van activa en passiva ook de conclusie worden getrokken dat, als proportionele consolidatie de beste methode is, de definitie van activa en passiva blijkbaar niet geheel adequaat is.
Ten slotte nog een zijdelingse opmerking over een verschil in terminologie bij verschillende disciplines. In het tweede artikel worden de partners in de joint venture aangeduid als de 'moederbedrijven'. Vanuit de externe verslaggeving zou dat een onjuiste term zijn: er is alleen sprake van een moederbedrijf ('parent entity') in relatie tot een dochterbedrijf('subsidiary') en dat betekent dat de moeder volledige zeggenschap heeft.

Het sluitstuk van het themanummer betreft de accountantscontrole van de joint venture. Zoals de auteurs Majoor en Van der Spek opmerken, is over dat specifieke onderwerp nog weinig geschreven. Dat is opvallend, gezien het veelvuldig voorkomen van joint ventures en gezien het feit dat er toch enige specifieke aspecten spelen die anders zijn dan bij de controle van (minderheids)deelnemingen en groepsmaatschappijen. De auteurs vullen het gat op door in te gaan op de volgende aspecten: de controle of er sprake is van een joint venture, de structuur van de accountantscontrole in groepsverbanden en de onafhankelijkheidsaspecten in relatie tot de joint venture. De analyses leiden tot enkele interessante bevindingen. Zo stellen de auteurs dat de ongedeelde verantwoordelijkheid voor groepsaccountants in veel situaties zal leiden tot hogere controlekosten waarbij de baten en lasten mogelijk niet in evenwicht zijn. Het vraagstuk van de ongedeelde verantwoordelijkheid staat sinds de uitspraak van het College van Beroep voor het bedrijfsleven ( $\mathrm{CBb}$ ) inzake de tuchtprocedure Deloitte/SOBI volop in de belangstelling. In het MAB van maart 2010 zal hier nader op worden ingegaan. Ook is er onduidelijkheid over de vraag of een groepsaccountant wel of niet onafhankelijk moet zijn van de joint venture waarin de groepsonderneming een partner is. Volgens de auteurs ligt hier een braakliggend terrein voor wetenschappelijk onderzoek naar de accountantscontrole van joint ventures.

Dit themanumer geeft een veelkleurig beeld van joint ventures. Het is interessant voor de controller die te maken heeft met beheersings- en verantwoordingsvraagstukken met betrekking tot joint ventures, voor de accountant die betrokken is bij de interne of externe controle van een joint venture, voor de studenten die accountant of controller willen worden, voor andere bedrijfseconomen en ook voor de wetenschapper: joint ventures mogen dan al lang bestaan, er zijn nog vele mogelijkheden voor interessant onderzoek. 